\title{
Bacterial carbohydrate-degrading capacity in foal faeces: changes from birth to pre-weaning and the impact of maternal supplementation with fermented feed products
}

\author{
Céline Faubladier*, Véronique Julliand, Justine Danel and Christelle Philippeau \\ AgroSup Dijon, URANIE - USC INRA Nutrition du cheval athlète, 21079 Dijon, France \\ (Submitted 18 April 2012 - Final revision received 4 December 2012 - Accepted 14 December 2012 - First published online 7 February 2013)
}

\begin{abstract}
The present study aimed at (1) describing age-related changes in faecal bacterial functional groups involved in carbohydrate degradation and in their activities in foals ( $n$ 10) from birth (day (d) 0$)$ to 6 months (d180) and (2) investigating the effect of maternal supplementation (five mares per treatment) from $\mathrm{d}-45$ to $\mathrm{d} 60$ with fermented feed products on response trends over time of the foal bacterial carbohydratedegrading capacity. Maternal supplementation with fermented feed products stimulated foal growth from d0 to d60 and had an impact on the establishment of some digestive bacterial groups and their activities in foals from d0 to d5 but not in the longer term. Irrespective of the maternal treatment, total bacteria, total anaerobic, lactate-utilising and amylolytic bacteria were established immediately after birth $(P<0.05)$ and were active as shown by the significant increase in total volatile fatty acids. In the foals of supplemented mares, total anaerobes and lactate utilisers were established rapidly between $\mathrm{d} 0$ and $\mathrm{d} 2(P=0.021$ and 0.066 , respectively) and the increase in the percentage of propionate occurred earlier $(P=0.013)$. Maternal supplementation had no effect on the establishment of fibrolytic bacteria and their activity. Cellulolytic bacteria and Fibrobacter succinogenes first appeared at $\mathrm{d} 2$ and $\mathrm{d} 5$, and increased progressively, reaching stable values at $\mathrm{d} 30$ and $\mathrm{d} 60$, respectively. From the second week of life, the increase in the molar percentage of acetate and the ratio (acetate + butyrate):propionate $(P<0.05)$ suggested that fibrolytic activity had begun. From d60, only minor changes in bacterial composition and activities occurred, showing that the bacterial carbohydrate-degrading capacity was established at 2 months of age.
\end{abstract}

Key words: Bacterial establishment: Carbohydrate degradation: Suckling foals: Maternal supplementation: Fermented feed products

In adult horses, one of the primary roles of the bacterial ecosystem in the large intestine is to break down parietal carbohydrates of plant cell walls, and to ferment them into volatile fatty acids (VFA) that, in turn, are absorbed across the intestinal wall, providing energy to the horse ${ }^{(1)}$. Ruminococcus flavefaciens, R. albus and Fibrobacter succinogenes have been described as the major cellulolytic bacterial species in the equine hindgut ${ }^{(2-5)}$. In addition to cellulolytic bacteria, amylolytic and lactate-utilising bacteria are other major functional groups in the hindgut of horses ${ }^{(6)}$ involved in the degradation of cytoplasmic carbohydrates that escape enzymatic digestion in the small intestine. The balance between the main functional bacterial groups is essential for optimising fibre degradation and depends greatly on the horse $\operatorname{diet}^{(7)}$.

In suckling foals, fibre rapidly becomes one major source of nutrients as suggested by the linear increase in grazing time with age while suckling activity decreases ${ }^{(8)}$. With respect to ruminants ${ }^{(9)}$, the bacterial degradation of fibre probably establishes the bacterial colonisation of the foal's hindgut. Information on the establishment of the foal intestinal ecosystem is sparse but some data are available from birth to 3 months of age. Meconium has been reported to be free of bacteria $^{(10)}$. Diverse maternal and environmental bacterial populations, such as enterococci, Enterobacteriaceae, Clostridia, lactobacilli and streptococci, have been shown to establish rapidly after birth $^{(10,11)}$. Using fingerprint techniques ${ }^{(12)}$, the bacterial pattern resembled the adult one within the first month of age, suggesting that the sequence of bacterial colonisation was complete. Although cellulolytic bacteria were detected between the third and fifth days of life in foal faeces and reached adult values at 2 months of age ${ }^{(13)}$, the age at which fibre-degrading capacity appears in the foal's hindgut is actually unknown. Previous studies ${ }^{(11,14)}$ reported that VFA were detectable from $1 \mathrm{~d}$ of life and peaked at $7 \mathrm{~d}$ of life in the faeces of foals, suggesting that bacterial fermentation occurred very rapidly in the hindgut. An in vitro study suggested that

Abbreviations: CFU, colony-forming units; VFA, volatile fatty acids.

* Corresponding author: C. Faubladier, fax +33 3 80772584, email c.faubladier@agrosupdijon.fr 
the capacity for fibre degradation in the foal by 1 month of age was similar to that in the mare ${ }^{(15)}$, but this was not confirmed in vivo.

As suggested in other species ${ }^{(16,17)}$, the establishment of the bacterial ecosystem in foals could have an impact on intestinal bacterial composition in adult horses and thus on digestive efficiency. Therefore, strategies increasing the beneficial microbial count and activity in the foal's hindgut during the neonatal period could optimise the bacterial ecosystem composition and activity later in life. As the maternal digestive microflora dominates the microbial environment in early life ${ }^{(18)}$, one strategy could consist of modifying the intestinal microflora of the mare ${ }^{(19)}$. In mice (20,21) and pigs $^{(22,23)}$, maternal dietary supplementation during gestation and lactation may influence in a beneficial way both the intestinal microflora of the dam and the establishment of bacterial communities in offspring, but this information is actually unknown in horses.

Microbial fermented feed products are used in pig nutrition to improve zootechnical performances ${ }^{(24-28)}$. Such products contain feed materials that are obtained by the fermentation of one or more microbes on specific media. In pigs supplemented with microbial fermented feed products, recent investigations reported an increase in bacterial richness and diversity $^{(26)}$, especially the Bacteroidetes and Lactobacillus populations ${ }^{(27)}$. These findings could suggest that microbial fermented products could have an impact on the intestinal microflora in mares, but no controlled studies have been reported in the peer-reviewed literature.

The present study aimed at (1) describing the age-related changes in bacterial functional groups involved in carbohydrate degradation and in their activities in foal faeces from birth to pre-weaning and (2) determining the effect of maternal supplementation with fermented feed products on response trends over time of the foal bacterial carbohydratedegrading capacity. This effect was tested during the period of supplementation (from birth to 2 months of age) and for a longer term (from 2 to 6 months).

\section{Materials and methods}

The experiment was conducted at the Animal Research Facility of AgroSup Dijon under experimental approval from the ethics committee of Burgundy University (agreement no. B1110).

\section{Animals and management}

A total of ten Haflinger mares (age: 10 (SD 4) years; body weight at $300 \mathrm{~d}$ of gestation: 571 (SD 35) kg) were included in the experiment from $45 \mathrm{~d}$ before foaling $(\mathrm{d}-45)$ until pre-weaning (180 d after foaling, d180). The day of foaling (d0) was determined by Ca determination in pre-foaling mammary secretion ${ }^{(29)}$ and foaling was induced by micro-injection of oxytocin ${ }^{(30)}$. The foals were used for the experiment at $\mathrm{d} 0$. From $\mathrm{d}-45$ to $\mathrm{d} 14$, the animals were kept in indoor individual free stalls with straw bedding during the night and in sandy paddocks during the day. From d14 to d180, mares and foals were maintained in sandy paddocks day and night. Mares and foals were wormed with Fenbendazole (Panacur ${ }^{\circledR}$; Intervet) at $\mathrm{d} 14$ and $\mathrm{d} 120$ and at $\mathrm{d} 90$ and $\mathrm{d} 150$, respectively. From d0 to d14, foals were checked daily for signs of diarrhoea. Foals were weighed at d1, then every week from d5 to d60, at d75, and once a month from d90 to d180.

\section{Experimental design and dietary treatment}

According to their age, parity, expected foaling date, body weight and intake level of hay at 10 months of gestation, mares were divided into two homogeneous groups in a block design. In the first group, mares ( $n$ 5, supplemented mares) were supplemented with two fermented feed products FAP $^{\circledR}$ (Original Process): EquiProcess ${ }^{\circledR}$ pellets $(360 \mathrm{~g} / \mathrm{d}$ from $\mathrm{d}-44$ to $\mathrm{d} 14 ; 240 \mathrm{~g} / \mathrm{d}$ from $\mathrm{d} 15$ to $\mathrm{d} 60$ in the morning concentrate meal) and FloreProcess ${ }^{\circledR}$ oral paste $(20 \mathrm{~g}$ at $30 \mathrm{~min}$ after foaling and every day at 11.00 hours from d1 to d3). Fermented feed products FAP $^{\circledR}$ contain feed materials obtained during the germination and fermentation of barley with eight deposited strains of lactic bacteria (National Collection of Micro-organisms Cultures at Institut Pasteur, France) through a specific process. Their composition is given in Table 1. These products contained none of the bacteria that was used during the process.

In the second group, mares ( $n$, control mares) did not receive any supplementation (control). The basal diet of mares (Table 2) was made up of meadow hay, a commercial pelleted feed (DP Evasion; InVivo NSA) and a soyabean meal. Hay was offered ad libitum and its intake level was measured during twenty-four consecutive hours every 2 weeks from $\mathrm{d}-45$ to $\mathrm{d} 90$, and then each month until d180. Daily amounts of the pelleted feed and soyabean meal were adjusted every 2 weeks depending on the average intake of hay to cover nutritional requirements of late pregnancy $^{(31)}$ and lactation $^{(32)}$. Concentrate feeds were provided in two equal meals at 08.00 and 17.30 hours until $\mathrm{d} 105$, and then in one meal at 08.00 hours until d180. From d-45 to d180, mineral pellets $(150 \mathrm{~g} / \mathrm{d}$, Prelac Star; InVivo NSA) were provided in the morning meal of concentrate.

Table 1. Chemical composition of EquiProcess ${ }^{\circledR}$ pellets and FloreProcess ${ }^{\circledR}$ paste

\begin{tabular}{lcc}
\hline & EquiProcess $^{\circledR}$ & FloreProcess $^{\circledR}$ \\
\hline DM (g/kg) & $880 \cdot 0$ & 229.4 \\
OM (g/kg DM) & 973.0 & 871.8 \\
Nutrients (g/kg DM) & & \\
CP & 116.0 & 48.0 \\
Fat & 35.0 & $\mathrm{ND}$ \\
CF & 54.0 & 49.7 \\
Neutral-detergent fibre & 163.7 & 130.3 \\
Resistant starch & 10.9 & $\mathrm{ND}$ \\
Starch & 537.4 & 131.9 \\
Free sugars & 49.3 & $\mathrm{ND}$ \\
Organic acids (mmol/kg DM) & & \\
Lactic acid & 37.5 & 467.7 \\
Acetic acid & 9.5 & 1071.9 \\
Propionic acid & 1.6 & 149.4 \\
\hline
\end{tabular}

OM, organic matter; $\mathrm{CP}$, crude protein; ND, not detected; $\mathrm{CF}$, crude fibre. * Free sugars $=$ glucose + fructose + sucrose + maltose 
Table 2. Chemical composition of hay, mare and foal pelleted food and soyabean meal

\begin{tabular}{|c|c|c|c|c|}
\hline & $\begin{array}{l}\text { Hay } \\
(\mathrm{g} / \mathrm{kg})\end{array}$ & $\begin{array}{c}\text { Mare } \\
\text { pelleted } \\
\text { food }^{*}(\mathrm{~g} / \mathrm{kg})\end{array}$ & $\begin{array}{c}\text { Foal } \\
\text { pelleted } \\
\text { food† }(\mathrm{g} / \mathrm{kg})\end{array}$ & $\begin{array}{c}\text { Soyabean } \\
\text { meal } \\
(\mathrm{g} / \mathrm{kg})\end{array}$ \\
\hline DM & 879.8 & 889.9 & 885.9 & $885 \cdot 2$ \\
\hline OM‡ & 934.2 & $919 \cdot 2$ & 920.2 & 926.5 \\
\hline $\mathrm{CP} \ddagger$ & $75 \cdot 7$ & $130 \cdot 6$ & 188.3 & 517.6 \\
\hline Fatł & NA & 33.7 & 39.5 & NA \\
\hline CF $\ddagger$ & 321.8 & $153 \cdot 4$ & 107.5 & 55.5 \\
\hline $\begin{array}{l}\text { Neutral- } \\
\text { detergent } \\
\text { fibre‡ }\end{array}$ & 639.8 & $419 \cdot 7$ & $303 \cdot 8$ & $119 \cdot 8$ \\
\hline Starch $\ddagger$ & NA & $151 \cdot 0$ & $178 \cdot 0$ & NA \\
\hline $\begin{array}{l}\text { Net energy } \\
(\mathrm{MJ} / \mathrm{kg}) \mp \S\end{array}$ & $4 \cdot 88$ & 8.52 & 9.29 & 7.35 \\
\hline
\end{tabular}

OM, organic matter; $\mathrm{CP}$, crude protein; NA, not analysed; CF, crude fibre.

* The pelleted food for mares had the following composition on a DM basis (\%): wheat bran $(32 \%)$; wheat shorts $(16 \%)$; barley $(15 \%)$; dehydrated alfalfa $(10 \%)$ straw $(9.4 \%)$; soyabean husks $(5 \%)$; sugar cane molasses; pomace; vitamin; mineral premix.

†The pelleted food for foals had the following composition on a DM basis (\%): wheat bran $(38 \%)$; barley $(18 \%)$; soyabean meal $(11 \%)$; alfalfa $(8 \%)$; whea shorts $(10 \%)$; sugar beet molasses $(5 \%)$; oat husks; malt sprouts; vitamin; mineral premix.

‡DM basis.

$\S$ Calculating from the nutritional composition ${ }^{(68)}$

Suckling foals did not receive any supplementation. From d0 to d105, they had no access to the mares' concentrate and had limited access to the mares' hay provided in elevated hayracks $(>1.1 \mathrm{~m})$ in order to limit ingestion of hay. From d105 to d180, suckling foals had free access to hay offered ad libitum and received a commercial pelleted feed (DP Evolution; InVivo NSA; Table 2) distributed in one meal at 17.00 hours $(0.3 \mathrm{~kg} \mathrm{DM} / \mathrm{d}$ from d105 to d150; $0.6 \mathrm{~kg} \mathrm{DM} / \mathrm{d}$ from $\mathrm{d} 150$ to $\mathrm{d} 180)$ to cover the energy and protein requirements of suckling foals ${ }^{(33)}$. Water and a block of salt were offered free-choice to all animals.

\section{Collection procedure and sampling}

In mares, faecal samples were collected manually from the rectum using single-use, but not sterile, gloves before foaling at $\mathrm{d}-45$ ( $1 \mathrm{~d}$ before the beginning of the dietary treatment), $d-30$ and $d-1$ (within the last 3 weeks before foaling) and after foaling at d1, d5, d10, d14, d30 and d60. A subsample of $1 \mathrm{~g}$ of faecal material was immediately diluted under $\mathrm{O}_{2}$-free $\mathrm{CO}_{2}$ in $9 \mathrm{ml}$ of an anaerobic mineral solution $^{(34)}$ for microbial analysis. A second subsample of about $100 \mathrm{~g}$ was filtered (Blutex $100 \mu \mathrm{m}$ ). The filtered content was divided into aliquots and frozen for further determination of VFA concentrations ( $1 \mathrm{ml}$ mixed with $0.1 \mathrm{ml}$ of a preservative solution consisting of $4.25 \%(\mathrm{v} / \mathrm{v}) \mathrm{H}_{3} \mathrm{PO}_{4}$ and $1.0 \%$ (w/v) $\mathrm{HgCl}_{2}$ ).

In foals, a rectal smear was obtained with a sterile swab (IMV Technologies) after cleaning the anus with a $10 \%(\mathrm{v} / \mathrm{v})$ iodine solution (Vétédine solution, Vétoquinol) within $20 \mathrm{~min}$ after birth to check the presence of total anaerobes. Meconium (d0) was collected in the rectum of foals using sterile gloves within $3 \mathrm{~h}$ maximum after birth. Faecal samples were taken directly from the rectum of foals using single-use, but not sterile, gloves, every day from d1 to d7, at d10, and every 2 weeks from $\mathrm{d} 30$ to $\mathrm{d} 90$ at $\mathrm{d} 14$, and then every month until d180. A subsample of $1 \mathrm{~g}$ of faecal material was immediately diluted in $9 \mathrm{ml}$ of an anaerobic mineral solution ${ }^{(34)}$ in the same conditions as described for mares and used for microbial analysis. Furthermore, one part of the faecal dilution was also divided into two aliquots and immediately frozen $\left(-20^{\circ} \mathrm{C}\right)$ for further determination of VFA concentrations as described for mares. A second subsample of about $10 \mathrm{~g}$ of faecal material was immediately frozen at $-20^{\circ} \mathrm{C}$ in hermetically sealed plastic boxes for further molecular analysis.

\section{Analysis of bacterial functional groups}

Serial decimal dilutions of the faecal samples were prepared under $\mathrm{O}_{2}$-free $\mathrm{CO}_{2}$ in an anaerobic mineral solution ${ }^{(34)}$ for inoculation on specific media.

Total viable anaerobic bacteria and lactate-utilising bacteria were enumerated following the roll-tube procedure under $\mathrm{O}_{2}$-free $\mathrm{CO}_{2}$ in a non-selective medium ${ }^{(3,35)}$ and in a selective medium containing $2 \%(\mathrm{v} / \mathrm{v})$ lactate as the sole energy source ${ }^{(36)}$, respectively. Bacterial numbers were determined after $48 \mathrm{~h}$ of incubation at $38^{\circ} \mathrm{C}$ from three replicate roll tubes prepared per dilution.

Amylolytic bacteria were deeply inoculated on an adapted medium containing $1 \%(\mathrm{w} / \mathrm{v})$ soluble starch as the main energy source ${ }^{(37)}$. For each dilution, three replicate Petri plates were inoculated. For bacterial counts, iodine solution was added to Petri plates after $48 \mathrm{~h}$ of incubation at $38^{\circ} \mathrm{C}$.

Cellulolytic bacteria were enumerated in a complex liquid medium $^{(3,38)}$ containing a strip of filter paper (Whatman no. 1) as the sole energy source. After an incubation of 2 weeks of three replicate tubes per dilution at $38^{\circ} \mathrm{C}$, the most probable number of cellulolytic bacteria in the faecal sample was determined using McGrady's tables ${ }^{(39)}$.

\section{DNA extraction and real-time quantitative PCR}

Faecal samples obtained from foals at d0, d1, d3, d5, d10, d14, $\mathrm{d} 30$ and then every month until d180 were used for real-time PCR quantification of total bacteria and F. succinogenes.

Total DNA was extracted from $0 \cdot 25 \mathrm{~g}$ of pure bacterial and faecal samples according to the bead-beating procedure ${ }^{(40)}$. DNA concentration was determined by measuring absorbance at $260 \mathrm{~nm}$.

DNA amplifications were performed using the Biorad iCycler iQ5 (Bio-Rad) with fluorescence detection of SYBR Green dye. Primer sequences were as follows: total bacteria (forward, 5'-CGGCAACGAGCGCAACCC; reverse, 5'-CCATTGTAGCACGTGTGTTAGCC) and F. succinogenes (forward, 5'-GTTCGGAATTACTGGGCGTAAA; reverse, 5'-CGCCTGCCCCTGAACTATC $)^{(41)}$. All DNA samples from the faeces and pure bacterial samples were diluted 100 -fold in sterile re-distilled water before amplification to reduce inhibition. Amplification was carried out in a total volume of $25 \mu$ l containing $1 \times$ IQ SYBR Green Super Mix (Bio-Rad), forward and reverse primers 
(1 $\mu \mathrm{m}$ each) and DNA template $(5 \mu \mathrm{l})$. All the samples were prepared in duplicate. After an initial denaturation step at $95^{\circ} \mathrm{C}$ for $3 \mathrm{~min}$, amplification and quantification programmes were repeated forty-five times $\left(95^{\circ} \mathrm{C}\right.$ for $30 \mathrm{~s}, 60^{\circ} \mathrm{C}$ for $30 \mathrm{~s}$ and $72^{\circ} \mathrm{C}$ for $\left.1 \mathrm{~min}\right)$. Amplification was followed by the melting curve programme $\left(72-95^{\circ} \mathrm{C}\right.$ for $\left.23 \mathrm{~min}\right)$ with a continuous fluorescence measurement. Negative controls without a DNA template were run with every assay. For each measurement, the mean threshold cycle $\left(C_{\mathrm{t}}\right)$ value was calculated.

$F$. succinogenes $\mathrm{S} 85$ was grown during $48 \mathrm{~h}$ in cellobiose (liquid medium) ${ }^{(42)}$ at $38^{\circ} \mathrm{C}$. The most probable number of F. succinogenes was determined using McGrady's tables ${ }^{(39)}$ before DNA extraction. The extracted DNA of $F$. succinogenes cells was diluted in serial decimal dilution and further quantified by real-time PCR using the primer set targeting $F$. succinogenes species. The standard curve was generated by plotting the observed $C_{\mathrm{t}}$ values $v$. bacterial concentration $\left(\log _{10}\right.$ cells $\left./ \mathrm{ml}\right)$. The standard curve for the absolute quantification of total bacteria was generated using the same procedure with the primer set targeting total bacteria. Standard curves were linear over the range of cell concentrations from $2.4 \log _{10}$ to $6.4 \log _{10}$ cells/ml (data not shown). When PCR was performed on unknown faecal samples, we used these standard curves to quantify each bacterial population. The extracted DNA of faecal samples was diluted 100 times for the PCR process, the detection limit being $4 \cdot 4 \log _{10}$ cells/g fresh faeces.

\section{pH measurement and volatile fatty acid analysis}

All samples were analysed in duplicate. Immediately after sampling, $\mathrm{pH}$ was determined using a $\mathrm{pH}$ meter $(\mathrm{pH} 510$; EUTECH Instruments Europe B.V.), which was calibrated using certified $\mathrm{pH} 4,7$ and 10 buffer solutions on fresh faecal matter in foals and on filtered faecal content in mares.

VFA concentrations in faecal samples were determined by GLC (Clarus ${ }^{\circledR} 500$ Gas Chromatograph; PerkinElmer) following the procedure described by Jouany ${ }^{(43)}$. The ratio (acetate + butyrate):propionate was calculated ${ }^{(44)}$.

\section{Statistical analyses}

Before statistical analyses, the means of replicate were calculated for all data and logarithmic transformations were performed for bacterial concentrations.

For all data, we used mixed models with a repeatedmeasures design to test the main effects of maternal supplementation and the time of sampling and the interaction between maternal supplementation and the time of sampling using PROC MIXED on the Statistical Analysis System statistical software package ${ }^{(45)}$. With the REPEATED statement, we used the compound symmetric structure ${ }^{(46)}$. Time of sampling was the repeated measure and the animal nested in maternal supplementation was the subject. When the interaction or fixed effects were significant, least-squares means were separated using the pairwise $t$ test (PDIFF option in the LSMEANS statement). Statistical significance was accepted at $P<0.05$ and a trend was considered at $P<0 \cdot 1$. All presented data are expressed as least-squares means with their standard errors.

A first statistical analysis was performed on data obtained in foals from d0 to d60. A second statistical analysis was then done on foal data obtained after the end of maternal supplementation, from $\mathrm{d} 60$ to $\mathrm{d} 180$, to assess the long-term effect of maternal supplementation.

\section{Results}

\section{Zootechnical performances of foals}

The ten foalings spread from 16 April to 7 June. Every foal was viable at birth and had a normal status with regard to first standing, suckling and colostrum intake. During the first 2 weeks of life, one foal of the control mare group presented minor diarrhoea during $1 \mathrm{~d}$ and five foals of the supplemented mares during $1.8(\mathrm{SD} 0.4) \mathrm{d}$, but did not need any specific medical care.

Foals suckling the supplemented mares were heavier at d19 $(P=0.048), \mathrm{d} 26(P=0.028), \mathrm{d} 40(P=0.041), \mathrm{d} 54(P=0.005)$ and d60 $(P<0 \cdot 001)$ than those from the control mares (Fig. 1).

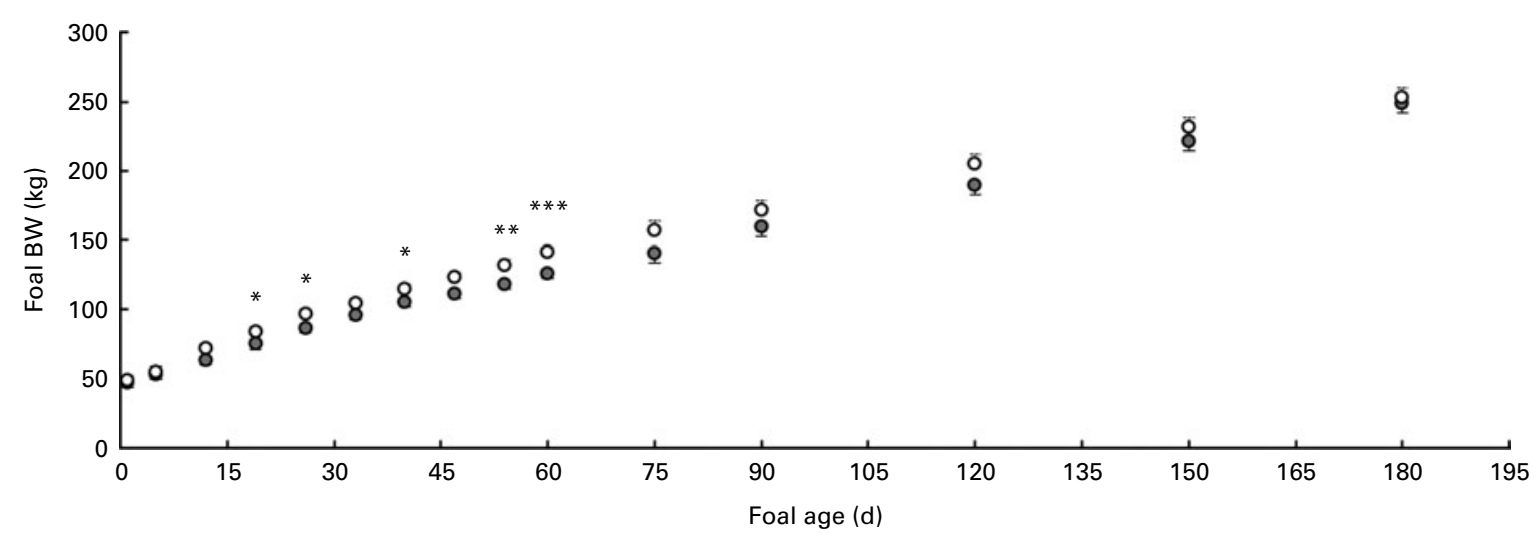

Fig. 1. Body weight $(\mathrm{BW})$ of the foals of control mares $(n 5,0)$ and supplemented mares $(n 5,0)$ from 1 to $180 \mathrm{~d}$ of life. Values are adjusted means, with their standard errors represented by vertical bars. From day (d) 1 to $d 60$, there was a significant maternal supplementation $\times$ age interaction $(P<0.05)$. From d60 to d180, there was no significant maternal supplementation $\times$ age interaction $(P>0.05)$, no effect for maternal supplementation $(P>0.05)$, but a significant effect for age $(P<0.001)$. Mean values were significantly different for the same age between the groups of foals: ${ }^{\star} P<0 \cdot 05,{ }^{\star \star} P<0.01,{ }^{\star \star \star} P<0.001$. 
The average daily gain was 1.55 (SD $0 \cdot 15$ ) and 1.34 $(\mathrm{SD} 0 \cdot 19) \mathrm{kg} / \mathrm{d}$ in the foals of supplemented mares and in the foals of control mares, respectively. From d60, maternal supplementation had no effect on the body weight of foals. The average daily gain was on average $0.98(\mathrm{SD} 0 \cdot 11) \mathrm{kg} / \mathrm{d}$.

\section{Faecal bacterial ecosystem of mares}

Supplementation did not affect the faecal bacterial concentrations of total anaerobic, amylolytic, lactate-utilising and cellulolytic bacteria from $\mathrm{d}-45$ to $\mathrm{d} 60$. Total anaerobic, amylolytic and cellulolytic bacterial counts were stable from $\mathrm{d}-45$ to $\mathrm{d} 60$, and were on average 8.2 (SD 0.48$) \log _{10}$ colony-forming units (CFU)/g fresh faeces, 5.5 (SD 0.68) $\log _{10}$ $\mathrm{CFU} / \mathrm{g}$ fresh faeces and 6.2 (SD 0.77) $\log _{10}$ most probable number/g fresh faeces, respectively. From $d-45$ to $d 0$, lactate-utilising bacterial counts were stable and were on average $6 \cdot 1$ (SD 0.58) $\log _{10} \mathrm{CFU} / \mathrm{g}$ fresh faeces. Then, they increased significantly from $\mathrm{d}-1$ to $\mathrm{d} 1\left(+0.6 \log _{10} \mathrm{CFU} / \mathrm{g}\right.$ fresh faeces, $P=0.035)$ and tended to decrease from $\mathrm{d} 5$ to $\mathrm{d} 60\left(-0.5 \log _{10} \mathrm{CFU} / \mathrm{g}\right.$ fresh faeces, $\left.P=0.053\right)$.

Faecal $\mathrm{pH}$ and total VFA concentration were not affected by the supplementation or the day of sampling from $d-45$ and $\mathrm{d} 60$, and were on average 6.6 (SD 0.33 ) and 64.0 (SD 16.57$) \mu \mathrm{mol} / \mathrm{ml}$, respectively (data not shown). The VFA profile was not affected by the day of sampling from $\mathrm{d}-45$ to d60; however, irrespective of the day of sampling, supplemented mares had a higher molar proportion of acetate than the control mares ( $P=0 \cdot 046$; Table 3$)$.

\section{Faecal bacterial communities of foals}

During maternal supplementation (from day 0 to day 60). Rectal smears were performed within 20 min after birth and contained less than $10 \mathrm{CFU}$ per swab for eight foals, and 33.6 and $647 \mathrm{CFU}$ total anaerobes per swab for one foal of control mares and supplemented mares, respectively.
Meconium collected on average $2 \cdot 0$ (SD 1.0) h after birth was not sterile irrespective of the method used (culture $v$. molecular method; Figs. 2 and 3 and Table 4). No cellulolytic bacteria were detected in the meconium.

Data of $\mathrm{d} 4$ and $\mathrm{d} 6$ are not presented on the plotted points for clarity in the figures.

There was a significant interaction between the age of foal and maternal supplementation for the total anaerobic counts from d0 to d60 $(P=0 \cdot 021 ;$ Fig. 2$)$. This interaction tended to be significant for lactate-utilising bacterial counts from d0 to d60 ( $P=0.066$; Fig. 3). In both groups of foals, the concentration of total anaerobes and lactate utilisers increased from $\mathrm{d} 0$ to $\mathrm{d} 2$ $(P<0 \cdot 01)$. The magnitude of the increase between $\mathrm{d} 0$ and $\mathrm{d} 1$ was greater in the foals of supplemented mares than in the foals of control mares $\left(+6.64 v\right.$. $+4 \cdot 14 \log _{10} \mathrm{CFU} / \mathrm{g}$ fresh faeces for total anaerobes and $+7 \cdot 18 v \cdot+4 \cdot 55 \log _{10} \mathrm{CFU} / \mathrm{g}$ fresh faeces for lactate utilisers). The concentration of total anaerobes and lactate utilisers was significantly higher at $\mathrm{d} 1$ $(P<0.05)$ and numerically higher at $\mathrm{d} 2(P>0.05)$ in the foals of supplemented mares compared with the controls. No difference was detected between the groups from $\mathrm{d} 3$. Thereafter, in both groups of foals, total anaerobes and lactate utilisers were stable until $\mathrm{d} 10$ and $\mathrm{d} 14$, respectively, and decreased until d60 $(P<0.05)$. The mean concentrations of cellulolytic and amylolytic bacteria or their establishment from d0 to $\mathrm{d} 60$ were not affected by maternal supplementation (Figs. 2 and 3, respectively). Amylolytic bacteria increased significantly from d0 to $\mathrm{d} 2(P<0 \cdot 05)$. From d3 to $\mathrm{d} 60$, a minor variation in amylolytic bacterial concentration occurred and was on average 6.81 (SD 0.91) $\log _{10} \mathrm{CFU} / \mathrm{g}$ fresh faeces. By the culture method, cellulolytic bacteria were first detected at $\mathrm{d} 2$ and found to increase significantly between $\mathrm{d} 4$ and $\mathrm{d} 5(P=0.013)$. Thereafter, cellulolytic bacterial concentration increased progressively, reaching stable values at $\mathrm{d} 30(P<0 \cdot 05)$.

Real-time quantitative PCR revealed that maternal supplementation did not affect the mean concentration of F. succinogenes and total bacteria and their establishment.

Table 3. Molar proportions of the main volatile fatty acids (VFA) and (acetate + butyrate):propionate in the fresh faeces of mares from $45 \mathrm{~d}$ before foaling (day (d) -45 ) to $60 \mathrm{~d}$ after foaling (d60) depending on the supplementation with fermented feed products*

(Adjusted means values with their highest standard errors)

\begin{tabular}{|c|c|c|c|c|c|c|c|c|c|c|c|c|}
\hline \multirow[b]{2}{*}{ Items and maternal groups } & \multicolumn{9}{|c|}{ Days } & \multirow[b]{2}{*}{ SEM } & \multicolumn{2}{|c|}{$P \dagger$} \\
\hline & $d-45$ & $d-30$ & $d-1$ & d1 & d5 & $\mathrm{d} 10$ & d14 & d30 & d60 & & $\mathrm{s}$ & $\mathrm{T}$ \\
\hline \multicolumn{13}{|l|}{ Acetate:total VFA (\%) } \\
\hline Control & $74 \cdot 3$ & 74.9 & 74.6 & $72 \cdot 8$ & 73.8 & $72 \cdot 3$ & $74 \cdot 8$ & $74 \cdot 6$ & 75.5 & 1.22 & 0.046 & 0.820 \\
\hline Supplemented & $76 \cdot 7$ & $77 \cdot 3$ & $76 \cdot 3$ & $76 \cdot 3$ & $77 \cdot 1$ & $76 \cdot 7$ & $74 \cdot 6$ & $76 \cdot 2$ & $76 \cdot 3$ & & & \\
\hline \multicolumn{13}{|l|}{ Propionate:total VFA (\%) } \\
\hline Control & $15 \cdot 7$ & $16 \cdot 5$ & $16 \cdot 5$ & $18 \cdot 4$ & $16 \cdot 5$ & $17 \cdot 0$ & $16 \cdot 6$ & $16 \cdot 7$ & $15 \cdot 9$ & 0.87 & 0.061 & 0.072 \\
\hline Supplemented & $14 \cdot 4$ & $14 \cdot 3$ & $14 \cdot 1$ & $16 \cdot 1$ & $15 \cdot 2$ & $15 \cdot 2$ & $16 \cdot 7$ & $15 \cdot 6$ & $14 \cdot 4$ & & & \\
\hline \multicolumn{13}{|l|}{ Butyrate:total VFA (\%) } \\
\hline Control & 4.9 & 4.4 & 4.2 & 4.5 & 4.4 & 4.7 & $4 \cdot 3$ & $4 \cdot 1$ & $4 \cdot 1$ & 0.51 & 0.673 & 0.286 \\
\hline Supplemented & 4.9 & $4 \cdot 6$ & $5 \cdot 0$ & $4 \cdot 8$ & $4 \cdot 3$ & 4.5 & $5 \cdot 0$ & $4 \cdot 2$ & $4 \cdot 7$ & & & \\
\hline \multicolumn{13}{|c|}{ (Acetate + butyrate):propionate } \\
\hline Control & $5 \cdot 1$ & 4.9 & $4 \cdot 8$ & $4 \cdot 3$ & $4 \cdot 8$ & $4 \cdot 7$ & $4 \cdot 8$ & $4 \cdot 8$ & $5 \cdot 1$ & 0.36 & 0.059 & $0 \cdot 117$ \\
\hline Supplemented & 5.9 & 5.9 & $6 \cdot 0$ & $5 \cdot 1$ & 5.4 & 5.4 & 4.9 & $5 \cdot 2$ & $5 \cdot 7$ & & & \\
\hline
\end{tabular}

S, supplementation; T, time.

${ }^{*}$ Five mares per group.

†There was no significant interaction between supplementation and time on the fermentative parameters in mares $(P>0.05)$. 


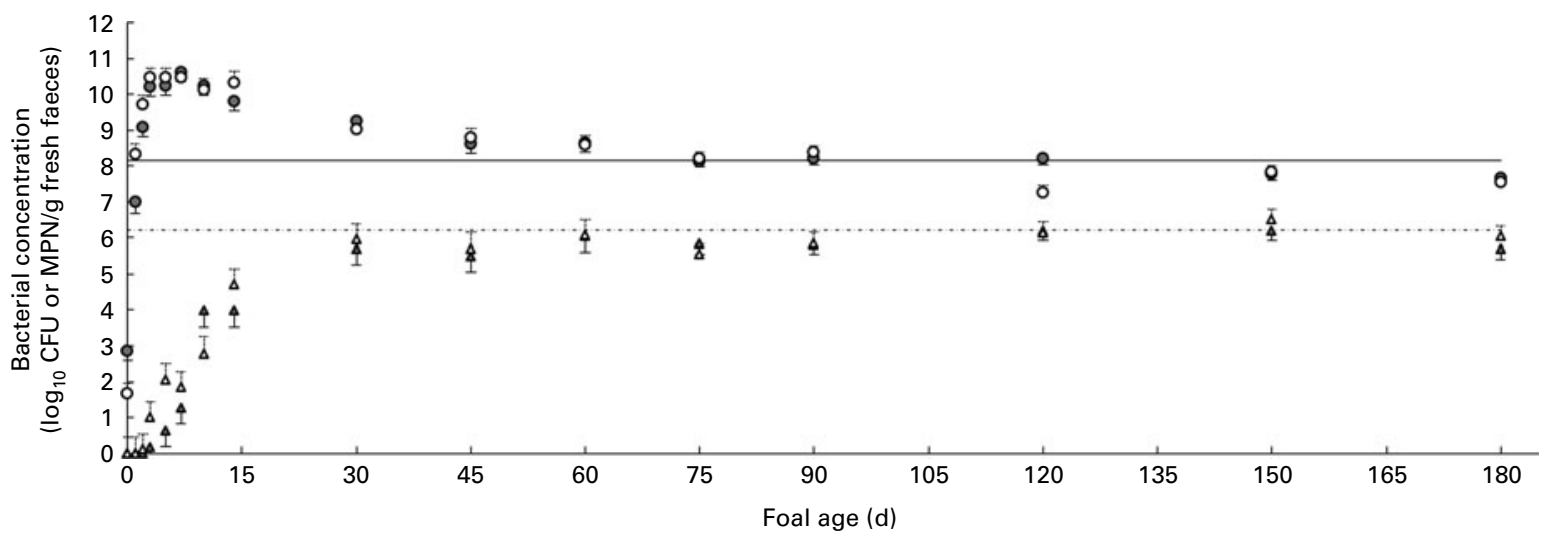

Fig. 2. Age-related changes in the viable cell number of total anaerobic $\left(\log _{10}\right.$ colony-forming units (CFU)/g) and cellulolytic bacteria (log ${ }_{10}$ most probable number (MPN)/g,) from birth to $180 \mathrm{~d}$ of age in the fresh faeces of foals (o, total anaerobes, foals of control mares; $\mathrm{O}$, total anaerobes, foals of supplemented mares; $\Delta$, cellulolytic bacteria, foals of control mares; $\Delta$, cellulolytic bacteria, foals of supplemented mares). Values are adjusted means, with their standard errors represented by vertical bars. For total anaerobes, there was a significant maternal supplementation $\times$ age interaction: $P=0.021$, from day (d) 0 to d60; $P=0.042$, from d60 to d180. For cellulolytic bacteria from d0 to d180, there was no significant maternal supplementation $\times$ age interaction $(P>0.05)$, no effect for maternal supplementation $(P>0.05)$, but a significant effect for age $(P<0.001)$. For cellulolytic bacteria from d60 to d180, there was no significant maternal supplementation $\times$ age interaction $(P>0.05)$, and no effects for age and maternal supplementation $(P>0.05)$. The mean value of mares was reported on the graph to represent the adult level of total anaerobes (-) and cellulolytic bacteria (........

This is why mean concentrations were averaged over maternal supplementation in Table 4. Total bacteria increased from d0 to d3 $(P<0 \cdot 001)$, reaching a stable plateau until d60. $F$. succinogenes was first detected at $\mathrm{d} 5$ and increased significantly from d30 to d60 $(P=0 \cdot 012)$.

After the end of maternal supplementation (from day 60 to day 180). There was a significant interaction between the age of foal and maternal supplementation only for the total anaerobic counts from d60 to $\mathrm{d} 180(P=0.042$; Fig. 2$)$. In both groups of foals, total anaerobes slowly decreased from d60 until d180, but the bacterial count at d120 was lower in the foals of supplemented mares compared with the foals of control mares $(P<0.001)$. Irrespective of the group of foals, the counts of lactate utilisers slowly decreased between d60 and d180 ( $P=0.002$; Fig. 3), whereas cellulolytic bacterial counts remained stable and were on average 6.06 (sD 0.63) $\log _{10}$ most probable number/g fresh faeces (Fig. 2). Amylolytic bacteria slowly decreased between d60 and d180 $(P<0.001$; Fig. 3) and irrespective of the day of sampling, except at $\mathrm{d} 75$, their mean concentration was lower in the foals of supplemented mares than those of control mares $(P=0 \cdot 008)$.

Real-time quantitative PCR revealed that maternal supplementation did not affect the mean concentrations of total bacteria and F. succinogenes after d60. Total anaerobes and $F$. succinogenes were stable after $\mathrm{d} 60$ and were on average 8.79 (SD 0.48) and $7.40(\mathrm{SD} 0.58) \log _{10} \mathrm{CFU} / \mathrm{g}$ fresh faeces, respectively (data not shown).

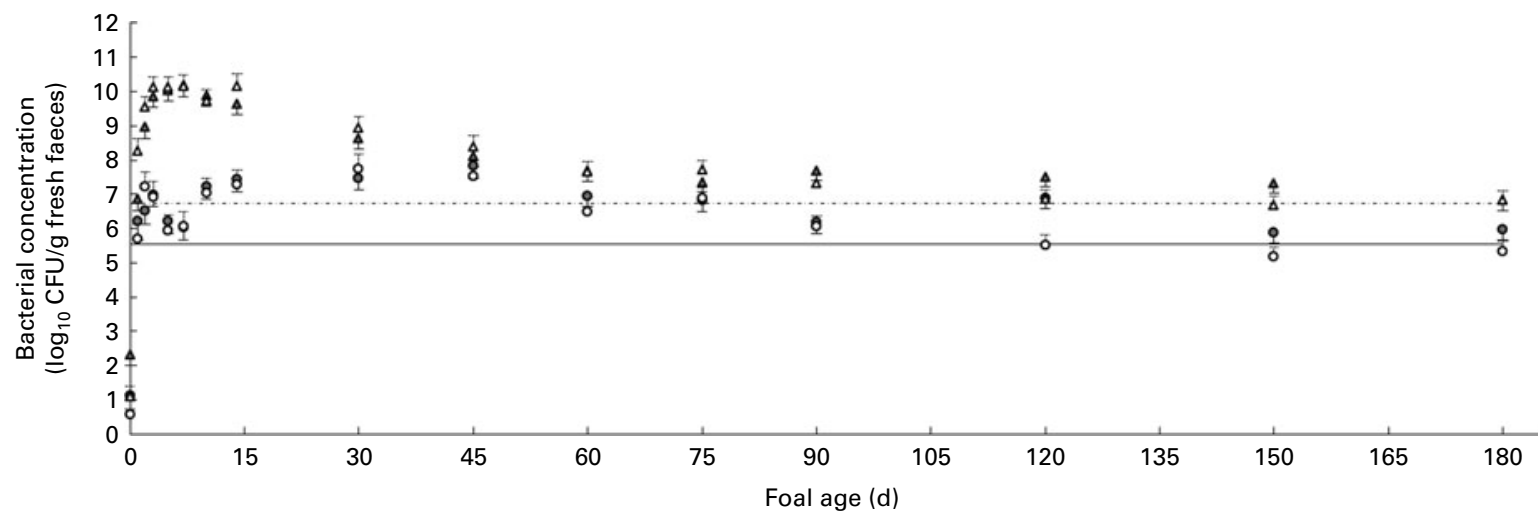

Fig. 3. Age-related changes in the viable cell number of amylolytic and lactate-utilising bacteria from birth to $180 \mathrm{~d}$ of age in the fresh faeces of foals (O, amylolytic bacteria, foals of control mares; $O$, amylolytic bacteria, foals of supplemented mares; $\Delta$, lactate utilisers, foals of control mares; $\Delta$, lactate utilisers, foals of supplemented mares). Values are adjusted means, with their standard errors represented by vertical bars. For amylolytic bacteria from day (d) 0 to d60, there was no significant maternal supplementation $\times$ age interaction $(P>0.05)$, no effect for maternal supplementation $(P>0.05)$, but a significant effect for age $(P<0.001)$. For amylolytic bacteria from d60 to d180, there was no significant maternal supplementation $\times$ age interaction $(P>0.05)$, but there were significant effects for maternal supplementation $(P=0.008)$, and borderline significant for age $(P<0.001)$. For lactate utilisers from d0 to d60, there was a maternal supplementation $\times$ age interaction $(P=0.066)$. For lactate utilisers from d60 to d180, there was no significant maternal supplementation $\times$ age interaction $(P>0.05)$, no effect for maternal supplementation $(P>0.05)$, but a significant effect for age $(P=0.033)$. The mean value of mares was reported on the graph to represent the adult level of amylolytic $(-)$ and lactate-utilising bacteria (........ . CFU, colony-forming units. 
Table 4. Quantification of total bacteria and Fibrobacter succinogenes using real-time quantitative PCR in the fresh faeces of foals from birth (day (d) 0 ) to $60 \mathrm{~d}$ of age $(\mathrm{d} 60)^{*}$

(Adjusted mean values with their highest standard errors)

\begin{tabular}{|c|c|c|c|c|c|c|c|c|c|c|}
\hline \multirow[b]{2}{*}{ Items† } & \multicolumn{8}{|c|}{ Days } & \multirow[b]{2}{*}{ SEM } & \multirow{2}{*}{$\frac{P}{\mathrm{~T}}$} \\
\hline & d0 & d1 & d3 & d5 & d10 & d14 & d30 & d60 & & \\
\hline Total bacteria ( $\log _{10}$ cells/g fresh faeces) & 4.89 & $6 \cdot 25$ & $8 \cdot 29$ & 8.34 & 8.25 & 8.05 & 8.56 & $8 \cdot 14$ & 0.249 & $<0.001$ \\
\hline F. succinogenes ( $\log _{10}$ cells/g fresh faeces) & $\mathrm{NE}$ & $\mathrm{NE}$ & $\mathrm{NE}$ & $5 \cdot 11$ & 5.55 & 5.97 & 5.99 & 6.85 & 0.554 & 0.017 \\
\hline
\end{tabular}

T, age of foals; NE, non-estimated.

${ }^{*}$ For ten foals.

†As there was no effect of maternal supplementation and no significant interaction between maternal supplementation and the age of foal, means were averaged over the maternal groups.

\section{Faecal fermentative parameters in foals}

During maternal supplementation (from day 0 to day 60).

Data of $\mathrm{d} 4$ and $\mathrm{d} 6$ are not presented on the plotted points for $\mathrm{pH}$ and total VFA concentration and in tables for molar percentages of VFA for clarity in the tables and figures.

An interaction between the age of the foal and maternal supplementation was detected for faecal $\mathrm{pH}$ from d0 to d60 $(P=0.018$; Fig. 4(a)). In the foals of supplemented mares, faecal $\mathrm{pH}$ first decreased from $\mathrm{d} 1$ to $\mathrm{d} 2(P=0.010)$ and then increased between $\mathrm{d} 2$ and $\mathrm{d} 3(P=0.023)$. In the foals of control mares, similar significant changes were observed with a delay of $1-2 \mathrm{~d}$. This resulted in lower faecal $\mathrm{pH}$ at $\mathrm{d} 2$ $(P=0.005)$ and higher faecal pH at $\mathrm{d} 4(P=0.009)$ in the foals of supplemented mares compared with the foals of control mares. From d5, faecal $\mathrm{pH}$ remained stable until d30 and then decreased from $\mathrm{d} 30$ to $\mathrm{d} 45$ in both groups of foal $(P<0 \cdot 05)$.
Maternal supplementation did not affect the concentration of total VFA from d0 to d60 (Fig. 4(b)), but had an effect on the age-related change in the VFA profile (Table 5). The total VFA concentration first increased from $\mathrm{d} 2$ to $\mathrm{d} 3$ $(P=0 \cdot 007)$, reaching a high-level plateau until d10. Thereafter, total VFA concentration slowly decreased until d60 $(P<0 \cdot 001)$. At $\mathrm{d} 0$ and $\mathrm{d} 1$, the molar percentage of acetate was very high and then decreased from $\mathrm{d} 1$ and $\mathrm{d} 5$ whereas the molar percentages of propionate and butyrate increased $(P<0 \cdot 05)$. These changes occurred earlier in the foals of supplemented mares than in those of control mares, resulting in a lower percentage of acetate at $\mathrm{d} 2$ and $\mathrm{d} 3(P=0.031$ and $P<0.001$, respectively) and a higher percentage of propionate at $\mathrm{d} 3$ and $\mathrm{d} 4(P=0.002$ and $P=0.004$, respectively) in the foals of supplemented mares compared with the controls. After d5, in both groups of foals, molar percentages were stable until d14. Then, the molar percentage of acetate slowly increased
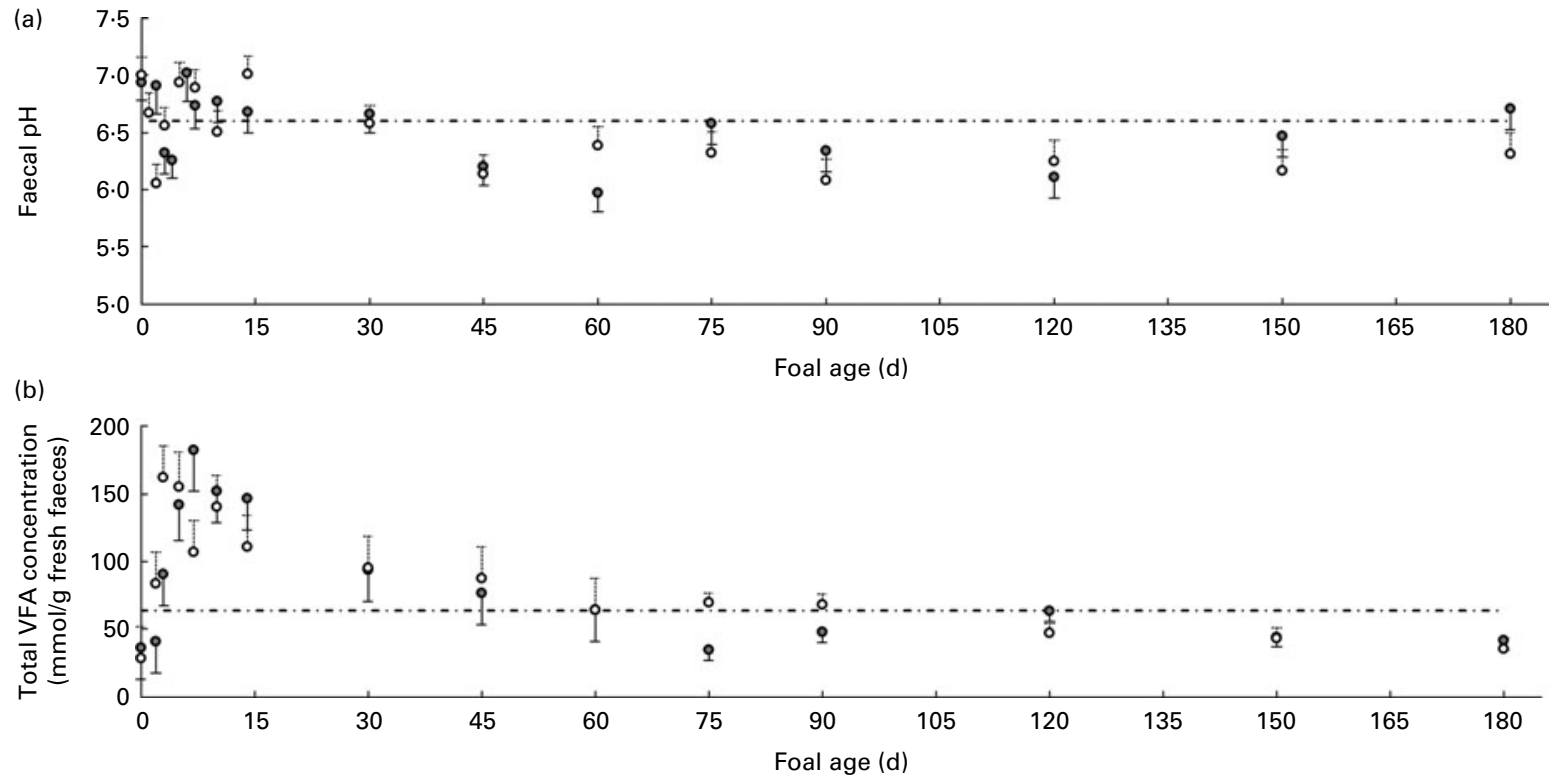

Fig. 4. Age-related changes in (a) $\mathrm{pH}$ and (b) total volatile fatty acid (VFA) concentration from birth to $180 \mathrm{~d}$ of age in the fresh faeces of foals of control mares $(n 5,0)$ and supplemented mares $(n 5,0)$. Values are adjusted means, with their standard errors represented by vertical bars. For $\mathrm{pH}$ from day (d) 0 to d60, there was a significant maternal supplementation $\times$ age interaction $(P=0.018)$. For $\mathrm{pH}$ from d60 to $\mathrm{d} 180$, there was no significant maternal supplementation $\times$ age interaction, and no effects for maternal supplementation and age $(P>0.05)$. For total VFA concentration from d0 to d60, there was no significant maternal supplementation $\times$ age interaction $(P>0.05)$, no effect for maternal supplementation $(P>0.05)$, but there was a significant effect for age $(P<0.001)$. For total VFA concentration from $\mathrm{d} 60$ to $\mathrm{d} 180$, there was a significant maternal supplementation $\times$ age interaction $(P=0.004)$. For each parameter, the mean value of mares was reported on the corresponding graph ( ....) to represent the adult level. 
until d60, whereas the molar percentages of propionate and butyrate slowly decreased $(P<0.05)$.

After the end of maternal supplementation (from day 60 to day 180). From d60 to d180, faecal $\mathrm{pH}$ was not affected by maternal supplementation and was stable over the period, and was on average 6.31 (SD 0.43) (Fig. 4(a)).

Maternal supplementation had an effect on total VFA concentration from d60 to d180 ( $P=0.004$; Fig. 4(b)), but did not affect the VFA profile (Table 6). In both groups of foals, total VFA concentration decreased between d60 and d180 $(P<0.05)$ but VFA concentration was higher at d75 $(P=0.002)$ and tended to be higher at $\mathrm{d} 90(P=0.055)$ in the foals of supplemented mares compared with that of controls. Irrespective of the maternal treatment, the molar percentage of propionate tended to increase and the (acetate + butyrate):propionate ratio decreased from $\mathrm{d} 90$ to $\mathrm{d} 120$ ( $P=0.054$ and $P=0.014$, respectively), whereas the molar percentages of acetate and butyrate were stable from d60 to $\mathrm{d} 180$.

\section{Discussion}

The process of bacterial establishment in the digestive tract of young animals plays an important role for host health and nutrition. Among several strategies developed to improve this process, we tested in the present study the impact of mare supplementation with fermented feed products around foaling. The present data confirmed previous data on the bacterial establishment in the foals' digestive tract from birth to 3 months of life, and provided new information about the bacterial carbohydrate-degrading capacity until 6 months of age, corresponding to the pre-weaning period. Moreover, this was the first investigation demonstrating the effect of maternal supplementation with fermented feed products around foaling on bacterial functional groups and their activities in foals.

\section{Establishment of the bacterial carbohydrate-degrading capacity in foals}

To characterise the establishment of the bacterial groups involved in carbohydrate degradation in foals, we used both conventional microbial methods and non-culture-dependent methods. Using culture techniques, we focused on cellulolytic, amylolytic and lactate-utilising bacteria, which are the main functional bacterial groups involved in carbohydrate degradation reported in adult horses ${ }^{(6)}$. As species-level detection was impossible using culture-based methods, we used real-time PCR quantification to focus on F. succinogenes that is one of the major fibrolytic bacterial strains in adult horses $^{(2,5)}$. Bacterial quantifications were completed by VFA determination in order to assess indirectly the fermentative activity of bacteria.

In accordance with the sterility of the digestive tract in utero ${ }^{(47,48)}$, the rectum contained no total anaerobes at birth. In contrast, the meconium collected $2 \mathrm{~h}$ after birth contained on average 4.91 (sD 0.18) $\log _{10}$ cells of total bacteria per $\mathrm{g}$ fresh faeces that were active as shown by the small amounts 
Table 6. Molar proportions of the main volatile fatty acids (VFA) and (acetate + butyrate):propionate ratio in the fresh faeces of foals from $60 \mathrm{~d}$ of age (d60) to $180 \mathrm{~d}$ of age (d180) depending on maternal supplementation with fermented feed products* (Adjusted means values with their highest standard errors)

\begin{tabular}{|c|c|c|c|c|c|c|c|c|c|c|}
\hline \multirow[b]{2}{*}{ Items and maternal treatments } & \multicolumn{6}{|c|}{ Days } & \multirow[b]{2}{*}{ SEM } & \multicolumn{3}{|c|}{$P$} \\
\hline & $\mathrm{d} 60$ & d75 & d90 & d120 & d150 & d180 & & $\mathrm{S}$ & $\mathrm{T}$ & $S \times T$ \\
\hline \multicolumn{11}{|l|}{ Acetate:total VFA (\%) } \\
\hline Control & $74 \cdot 0$ & $75 \cdot 4$ & $75 \cdot 7$ & $74 \cdot 3$ & $73 \cdot 1$ & $73 \cdot 1$ & \multirow[t]{2}{*}{1.83} & 0.319 & \multirow[t]{2}{*}{0.600} & \multirow[t]{2}{*}{0.894} \\
\hline Supplemented & 71.5 & 74.2 & 71.8 & $73 \cdot 7$ & 71.5 & 72.5 & & & & \\
\hline \multicolumn{11}{|l|}{ Propionate:total VFA (\%) } \\
\hline Control & $16 \cdot 9$ & $17 \cdot 3$ & $16 \cdot 9$ & $18 \cdot 3$ & $19 \cdot 0$ & $20 \cdot 1$ & \multirow[t]{2}{*}{$1 \cdot 15$} & 0.625 & \multirow[t]{2}{*}{0.013} & \multirow[t]{2}{*}{0.442} \\
\hline Supplemented & $18 \cdot 2$ & $16 \cdot 9$ & $17 \cdot 4$ & $19 \cdot 7$ & $21 \cdot 0$ & 18.9 & & & & \\
\hline \multicolumn{11}{|l|}{ Butyrate:total VFA (\%) } \\
\hline Control & $5 \cdot 3$ & 5.5 & $4 \cdot 3$ & $4 \cdot 6$ & 5.4 & $5 \cdot 2$ & \multirow[t]{2}{*}{0.85} & 0.733 & \multirow[t]{2}{*}{0.991} & \multirow[t]{2}{*}{0.571} \\
\hline $\begin{array}{l}\text { Supplemented } \\
\text { (Acetate }+ \text { butyrate):propionate }\end{array}$ & $5 \cdot 3$ & $5 \cdot 2$ & $6 \cdot 2$ & $5 \cdot 2$ & $4 \cdot 8$ & $5 \cdot 1$ & & & & \\
\hline Control & 4.9 & 4.7 & 4.8 & 4.4 & 4.3 & 4.0 & \multirow[t]{2}{*}{0.36} & 0.545 & \multirow[t]{2}{*}{0.044} & \multirow[t]{2}{*}{0.743} \\
\hline Supplemented & 4.3 & 4.8 & 4.7 & 4.0 & $3 \cdot 7$ & 4.2 & & & & \\
\hline
\end{tabular}

$\mathrm{S}$, maternal supplementation; $\mathrm{T}$, age of foal; $\mathrm{S} \times \mathrm{T}$, interaction between maternal supplementation and the age of the foal.

${ }^{*}$ Five foals per maternal group.

of VFA (25.6 (sD 17.32) $\mu \mathrm{mol} / \mathrm{g}$ fresh faeces). Although different from previous data in foals ${ }^{(10)}$, this was not completely surprising. Meconium has been reported to be non-sterile in human neonates ${ }^{(49,50)}$. During the first $3 \mathrm{~d}$ of life, a rapid and early establishment of total bacteria and strict anaerobes occurred, as reported previously in foals ${ }^{(10,11,13)}$. The present results showed that amylolytic and lactate-utilising bacteria were the first functional groups involved in carbohydrate degradation that were established in foals during the first 2 weeks of life. Amylolytic bacteria enumerated on Petri plates were probably streptococci or lactobacilli, as previously reported in foals ${ }^{(13)}$. Because no starch is available in milk, these bacteria were probably involved in the degradation of substrates other than starch such as lactose and other oligosaccharides that may escape the precaecal enzymatic digestion and enter the foal's hindgut, as reported in human subjects ${ }^{(51)}$. Shifts in fermentation end products measured during the first days of life could be explained by bacterial metabolic crossfeedings. During the first $3 \mathrm{~d}$, amylolytic bacterial activity could result in the production of acetate (about $88.6 \%$ of total VFA) and probably in lactate, as reported in previous studies in foal ${ }^{(10,11)}$ and calf faeces ${ }^{(52)}$. This could explain the acidification of $\mathrm{pH}$. From d3, the increase in the molar proportion of propionate and butyrate could suggest that lactate utilisers were then involved efficiently in the conversion of lactate to propionate and butyrate ${ }^{(53,54)}$. Concomitantly, faecal $\mathrm{pH}$ reached neutrality, confirming the decrease in lactate concentration, as reported in the faeces of calves ${ }^{(52)}$, known as a strong acid $\left(\mathrm{p} K_{\mathrm{a}}=3 \cdot 86\right)$. Moreover, the decrease in acetate concomitantly with the increase in butyrate could also result from the conversion of acetate by butyrateproducing bacteria ${ }^{(55)}$.

In accordance with the literature ${ }^{(8)}$, we observed foals eating forage from the second day of life. Forage intake is actually unknown but probably increased with age, as suggested by the grazing time that increased linearly while sucking activity decreased ${ }^{(8)}$. In suckling lambs, the intake of solid food increased significantly from the end of the first month of life $\mathrm{e}^{(56,57)}$. In parallel with the enhancement of forage intake rich in complex parietal carbohydrates, we observed the establishment of fibrolytic bacteria, as in the rumen of lambs ${ }^{(56)}$. In accordance with previous data in foal faeces $^{(13)}$ and lamb rumen ${ }^{(58)}$, cellulolytic bacteria first appeared at $\mathrm{d} 2$ and increased progressively, reaching stable values at $\mathrm{d} 30$. From the second week of life, the molar proportion of acetate and the ratio (acetate + propionate): butyrate increased. Such modifications in the VFA profile could result from cellulolytic activity and suggest that the bacterial fibre-degrading capacity appeared in the foal's hindgut. This is in agreement with observations in the rumen of milkfed calves where fibrolytic activity was detected during the first week of life as shown by the increase in xylanase activity from $\mathrm{d} 4$, reaching a maximal value at $\mathrm{d} 7^{(57)}$. When foals were 2 months old, the VFA profile remained constant and cellulolytic bacterial concentration was comparable with adult values similarly to what has been reported in the rumen of young ruminants $^{(9)}$. In accordance with Rey et al. ${ }^{(57)}$ reporting that the main ruminal fermentative and enzymatic activities are stabilised approximately 1 month of age in calves, the present data could suggest that the fibre-degrading capacity in foals was established at 2 months of age.

For quantifying specific fibrolytic bacterial strains in the faeces of foals, we used a complementary approach to the conventional culture-based method: real-time PCR technology based on the molecular analysis of the bacterial $16 \mathrm{~S}$ rRNA gene. In adult horses, the population of F. succinogenes was successfully estimated using competitive PCR assays ${ }^{(5)}$ or semi-quantitative real-time $\mathrm{PCR}^{(2)}$. In the present study, we used the real-time PCR assay with standard curves based on bacterial DNA from pure culture to perform the absolute quantification of $F$. succinogenes ${ }^{(41)}$. Similarly to cellulolytic bacteria establishment, $F$. succinogenes was first detected at d5 and increased significantly from d30 to d60 and reached high stable values (about $6.85 \log _{10}$ cells/g fresh faeces), 
suggesting that Fibrobacter could be one of the most abundant fibrolytic bacteria established in foals, as reported in calves ${ }^{(59,60)}$. Nevertheless, other fibrolytic bacterial strains, such as $R$. albus and $R$. flavefaciens that have been reported in adult horses ${ }^{(2,3,5)}$, may be present in foals.

In human infants, the structure of faecal bacterial communities shows a relative stability after $30 \mathrm{~d}$ of life and the bacterial composition may fluctuate slightly until weaning ${ }^{(61)}$. Similarly to this observation, only minor changes occurred in the foal faecal bacterial communities and activities after 2 months of age and were probably correlated with changes in the feeding behaviour of the foals. Indeed, milk consumption decreased following the decrease in mare milk production after the second month of lactation ${ }^{(62)}$. This could explain why counts of bacteria involved in lactate metabolism significantly decreased until 6 months of age. Moreover, we observed an increase in the molar percentage of propionate and a decrease in the (acetate + butyrate):propionate ratio from $\mathrm{d} 90$ to $\mathrm{d} 120$. This probably resulted from the degradation of starch contained in pellets into lactate by amylolytic bacteria, which was then converted to propionate by lactateutilising bacteria. The addition of pellets in the diet of foals aimed at covering the high nutrient requirement that exceeds the level of energy and protein supply provided by both ingested milk and forage at this age ${ }^{(33)}$. Such changes in bacterial activities have also been reported in the hindgut of adult horses, when the proportion of cereals increased in the ration ${ }^{(63)}$ and in the rumen of weaned lambs when concentrate intake increased $^{(57)}$.

At 6 months of age, the bacterial composition in foal faeces was similar to that of mares. Nevertheless, few differences persisted in bacterial fermentative activities as suggested by the (acetate + butyrate):propionate ratio that remained lower in foals compared with mares. As foals still suckled their mother before weaning, lactose and other oligosaccharides may have reached the hindgut and enhanced the activity of lactate-producing bacteria. As lactate could then be converted to propionate by lactate-utilising bacteria, this could explain the higher proportion of propionate that we measured in foals compared with mares. We also measured a higher proportion of butyrate and a lower proportion of acetate in foals compared with mares. This could be partly due to the conversion of lactate and acetate by butyrate-producing bacteria $^{(55)}$. This could also be explained by a less efficient fibre-degrading capacity in foals than in adult horses. Among the explanatory factors, the intake level of forage was certainly lower in foals compared with mares, as suggested by the time spent in grazing, which has been reported to be lower in foals compared with mares: approximately 48 and $80 \%$ of time, respectively, in animals with free access to pasture ${ }^{(8)}$. Another explanatory factor could be the retention time in the digestive tract of foals that may be shorter than in mares. Nevertheless, it is actually unknown in the suckling foal. Further investigations are needed to determine when the bacterial carbohydratedegrading capacity in the growing horse is similar to that of the adult horse.

\section{Effect of maternal supplementation on the bacterial digestive ecosystem in foals}

In the present study, maternal supplementation with fermented feed products had an effect on the early establishment of total anaerobes and lactate utilisers from do to d3. This result was correlated with significant effects of maternal supplementation on the age-related change in VFA profile and $\mathrm{pH}$ from $\mathrm{d} 1$ to $\mathrm{d} 5$. We hypothesised that these differences between the groups of foals could be due to (1) the modification of the bacterial ecosystem in mares and/or (2) an alteration in milk production.

In supplemented mares, no change in the bacterial composition was detected, but the molar proportion of acetate and the (acetate + butyrate):propionate ratio were higher, suggesting an improvement in bacterial fibrolytic activity. As reported in the faeces of weaned pigs supplemented with yeast fermentation products using real-time $\mathrm{PCR}^{(27)}$, it is probable that the composition of the intestinal microbiota was altered in mares. However, these changes could not be detectable using the conventional culture technique. Although little is known about bacterial colonisation modes of the foal's hindgut, the maternal microflora could be directly transmitted to the foal during and after the birth conditioned by the close contact between the newborn and its mother ${ }^{(64)}$. Nevertheless, another contamination mode of the foal's hindgut could be the mare's milk. Indeed, it was recently demonstrated in a mouse model that bacterial migration from the digestive tract lumen via blood cells to the breast occurred in lactating mothers ${ }^{(65)}$, suggesting that a mother-to-child efflux may exist during lactation and play a role in bacterial establishment in the digestive tract in neonates. This process could be confirmed by the presence of bacterial DNA detected in the milk of the mother ${ }^{(66)}$. Bacterial diversity has never been investigated in mare's milk. It could be an important source of maternal bacteria and/or bacterial DNA in the hindgut of suckling foals. To confirm or invalidate this hypothesis, further investigations on bacterial diversity in milk compared with that in foal and mare faeces are required.

In foals fed a commercial colostrum replacer at birth and once every 2 weeks during the first 3 months, fewer cellulolytic bacteria and fewer lactobacilli were counted in the faeces during the first 2 weeks of life ${ }^{(13)}$, suggesting that milk composition could have an impact on bacterial intestinal establishment in foals. As milk is the main nutrient source for foals in the neonatal period, a change in milk composition and/or in quantity could also explain the higher rate of growth in foals of supplemented mares, as reported in suckling piglets of sows supplemented with the Saccharomyces cerevisiae fermentation product ${ }^{(28)}$. In supplemented mares, as previously explained, the fibrolytic activity of the microflora could be improved. This could lead to a better utilisation of the daily ration and thus an increase in milk production, as suggested in sows supplemented with the $S$. cerevisiae fermentation product ${ }^{(28)}$. Nevertheless, no energetic placebo was used in the present experimental control mares and fermented feed products provided higher energy in the basal 
diet of mares $(+3 \cdot 8 \mathrm{MJ} / \mathrm{d})$, and thus may have increased the energy composition of milk ${ }^{(67)}$

After the end of maternal supplementation with fermented feed products, no difference in growth rate was observed between the two groups of foals. Moreover, only slight modifications in total anaerobic and amylolytic bacterial counts and VFA concentrations were detectable. In the rumen of lambs ${ }^{(16)}$, differential bacterial establishment in early life has shown to lead to differences in the structure of the bacterial communities that persisted after weaning. In the present study, it is not possible to explain the changes in the composition of the microbial communities in growing foals with regard to the differences observed in early bacterial establishment. Further investigations are required to explain these differences between the two groups of foals after 2 months of age.

\section{Conclusion}

The present study investigated for the first time the establishment of bacterial carbohydrate-degrading capacity in foals from birth to pre-weaning. The present results showed that the established bacterial communities were able to degrade fibre from 2 months of age, suggesting that suckling foals became herbivorous at a very early age, as young ruminants. Nevertheless, at the pre-weaning period, bacterial carbohydrate-degrading capacity in foals seemed not yet to be that of the adult. Moreover, the present results showed that maternal supplementation with fermented feed products stimulated foal growth and had an impact on the early establishment of some bacterial functional groups and their activities from $\mathrm{d} 0$ to $\mathrm{d} 5$ in foals but not in the longer term. The stimulation of growth could not be explained as such by a change in the microflora in foals.

\section{Acknowledgements}

The present study was supported by the Regional Council of Burgundy, the Fonds Eperon (Encouragement aux Projets Equestres Régionaux ou Nationaux) and Original Process. This study was done during the PhD of C. F. The authors' contributions were as follows: C. F., C. P. and V. J. were involved in the designing of the study and the writing of the manuscript; C. F. and J. D. were involved in the animal experiments, microbial analysis and data collection; C. F. performed the statistical analyses. None of the authors had a financial or personal conflict of interest in relation to the present study.

\section{References}

1. Argenzio RA, Southworth M \& Stevens CE (1974) Sites of organic acid production and absorption in the equine gastrointestinal tract. Am J Physiol 226, Suppl. 5, 1043-1050.

2. Hastie P, Mitchell K \& Ja M (2008) Semi-quantitative analysis of Ruminococcus flavefaciens, Fibrobacter succinogenes and Streptococcus bovis in the equine large intestinal using real-time polymerase chain reaction. BrJ Nutr 100, 561-568.

3. Julliand V, De Vaux A, Millet L, et al. (1999) Identification of Ruminococcus flavefaciens as the predominant cellulolytic bacterial species of the equine cecum. Appl Environ Microbiol 65, Suppl. 8, 3738-3741.

4. Lin C \& Stahl DA (1995) Taxon-specific probes for cellulolytic genus Fibrobacter reveal abundant and novel equine-associated populations. Appl Environ Microbiol 61, 1348-1351.

5. Koike S, Shingu Y, Inaba $\mathrm{H}$, et al. (2000) Fecal bacteria in Hokkaido native horses as characterized by microscopic enumeration and competitive polymerase chain reactions assays. J Equine Sci 11, 45-50.

6. Sadet-Bourgeteau S \& Julliand V (2010) Equine microbial gastro-intestinal health. In The Impact of Nutrition on the Health and Welfare of Horses, EAAP Publication no. 128, pp. 161-182 [AD Ellis, AC Longland, N Miraglia and $\mathrm{M}$ Coenen, editors]. Cirencester: Wageningen Academic Publishers.

7. Daly K, Proudman CJ, Duncan SH, et al. (2012) Alterations in microbiota and fermentation products in equine large intestine in response to dietary variation and intestinal disease. Br J Nutr 107, 989-995.

8. Crowell-Davis S, Houpt K \& Carnevale J (1985) Feeding and drinking behavior of mares and foals with free access to pasture and water. J Anim Sci 60, 883-889.

9. Fonty G, Jouany JP, Chavarot M, et al. (1991) Development of the rumen digestive functions in lambs placed in a sterile isolator a few days after birth. Reprod Nutr Dev 31, 521-528.

10. Sakaitani Y, Yuki N, Nakajima F, et al. (1999) Colonization of intestinal microflora in newborn foals. J Intest Microbiol 13, $9-14$.

11. Yuyama T, Yusa S, Takai S, et al. (2004) Evaluation of a hostspecific Lactobacillus probiotic in neonatal foals. Int J Appl Res Vet Med 2, Suppl. 1, 26-33.

12. Earing JE, Durig AC, Gellin GL, et al. (2012) Bacterial colonization of the equine gut; comparison of mare and foal pairs by PCR-DDGE. Adv Microb 2, 79-86.

13. Julliand V, de Vaux A, Villard L, et al. (1996) Preliminary studies on the bacterial flora of faeces taken from foals, from birth to twelve weeks. Effect of the oral administration of a commercial colostrum remplacer. Pferdebeilkunde $\mathbf{1 2}$, Suppl. 3, 209-212.

14. Sato H, Kurosawa T \& Oikawa S (2002) Concentrations of fecal volatile fatty acid and lactic acid in neonatal foals. JJpn Vet Med Assoc 55, 417-420.

15. Hayes S, Werner H \& Lawrence L (2003) In vitro assessment of fiber digestion capacity in foals. In Proceedings of the 18th Equine Nutrition and Physiology Sympsosium, East Lansing, MI, USA, pp. 273-274.

16. Yanez-Ruiz DR, Macias B, Pinloche E, et al. (2010) The persistence of bacterial and methanogenic archaeal communities residing in the rumen of young lambs. FEMS Microbiol Ecol 72, 272-278.

17. Thompson CL, Wang B \& Holmes AJ (2008) The immediate environment during postnatal development has long-term impact on gut community structure in pigs. ISME $J \mathbf{2}$, 739-748.

18. Mackie R, Sghir A \& Gaskins R (1999) Developmental microbial ecology of the neonatal gastrointestinal tract. Am J Clin Nutr 69, 1035S-1045S.

19. Thum C, Cookson AL, Otter DE, et al. (2012) Can nutritional modulation of maternal intestinal microbiota influence the development of the infant gastrointestinal tract? J Nutr $\mathbf{1 4 2}$, 1921-1928.

20. Fujiwara R, Watanabe J \& Sonoyama K (2008) Assessing changes in composition of intestinal microbiota in neonatal $\mathrm{BALB} / \mathrm{c}$ mice through cluster analysis of molecular markers. Br J Nutr 99, 1174-1177. 
21. Fujiwara R, Takemura N, Watanabe J, et al. (2010) Maternal consumption of fructo-oligasaccharide diminishes the severity of skin inflammation in offspring of NC/Nga mice. $\mathrm{BrJ}$ Nutr 103, 530-538.

22. Demeckova V, Kelly D, Coutts AGP, et al. (2002) The effect of fermented liquid feeding on the faecal microbiology and colostrum quality of farrowing sows. Int J Food Microbiol 79, 85-97.

23. Leonard S, Sweeney T, Bahar B, et al. (2011) Effect of dietary seaweed extracts and fish oil supplementation in sows on performance, intestinal microflora, intestinal morphology, volatile fatty acid concentrations and immune status of weaned pigs. Br J Nutr 105, 549-560.

24. Lessard M \& Brisson GJ (1987) Effect of a Lactobacillus fermentation product on growth, immune response and fecal enzyme activity in weaned pigs. Can J Anim Sci 67, 509-516.

25. Hale OM \& Newton GL (1979) Effects of viable Lactobacillus species fermentation product on performance in pigs. J Anim Sci $48,770-775$

26. Kiaries E, Bhandari S, Scott M, et al. (2010) Growth performance and gastrointestinal microbial ecology response of piglets receiving Saccharomyces cerevisiae fermentation products after an oral challenge with Escherichia coli (K88). J Anim Sci 89, 1062-1078

27. Price KL, Totty HR, Lee HB, et al. (2010) Use of Saccharomyces cerevisiae fermentation product on growth performance and microbiota of weaned pigs during Salmonella infection. J Anim Sci 88, 3896-3908.

28. Shen YB, Carroll JA, Yoon I, et al. (2011) Effects of supplementing Saccharomyces cerevisiae fermentation product in sow diets on performance of sows and nursing piglets. J Anim Sci 89, 2462-2471.

29. Drogoul C, Clément F, Ventorp M, et al. (2006) Equine colostrum production and utilisation: basic and applied aspects. In Nutrition and Feeding the Broodmare, EAAP publication no. 120, pp. 203-219 [N Miraglia and W Martin-Rosset, editors]. Campobasso: Wageningen Academic Publishers.

30. Camillo F, Marmorini S, Romagnoli S, et al. (2000) Clinical studies on daily low dose of oxytocin in mare at term. Equine Vet J 32, 307-310.

31. Martin-Rosset W, Vervuert I \& Austbo D (2006) Energy and protein requirements and recommended allowances in pregnant mares. In Nutrition and Feeding the Broodmare, EAAP publication no. 120, pp. 15-39 [N Miraglia and $\mathrm{W}$ Martin-Rosset, editors]. Campobasso: Wageningen Academic Publishers.

32. Martin-Rosset W, Austbo D \& Coenen M (2006) Energy and protein requirements and recommended allowances in lactating mares. In Nutrition and Feeding the Broodmare, EAAP publication no. 120, pp. 89-115 [N Miraglia and $\mathrm{W}$ Martin-Rosset, editors]. Campobasso: Wageningen Academic Publishers

33. Martin-Rosset W, Younge B. (2006) Energy and protein requirements and feeding of the suckling foal. In Nutrition and Feeding the Broodmare, EAAP Publication no. 120, pp. 221-244 [N Miraglia and W Martin-Rosset, editors]. Campobasso: Wageningen Academic Publishers.

34. Bryant M \& Burkey L (1953) Cultural methods and some characteristics of some of the more numerous groups of bacteria in the bovine rumen. J Dairy Sci 36, 205-217.

35. Leedle J \& Hespell R (1980) Differential carbohydrate media and anaerobic replica plating techniques in delineating carbohydrate-utilizing subgroups in rumen bacteria populations. Appl Environ Microbiol 34, 709-719.
36. Mackie R \& Heath A (1979) Enumeration and isolation of lactate utilizing bacteria from the rumen of sheep. Appl Environ Microbiol 38, 416-421.

37. Varloud M. (2006) Implication des micro-organismes de l'estomac dans la digestion de l'amidon chez le cheval (Involvement of microorganisms from the stomach in the starch digestion in horses). Thèse de doctorat 3ème cycle, Ecole doctorale ABIES, INA-PG, Paris, France.

38. Halliwell G \& Bryant M (1963) The cellulolytic activity of pure culture strains of bacteria from the rumen of cattle. J Gen Microbiol 32, 441-448.

39. Clarke K \& Owens N (1983) A simple and versatile microcomputer program for the determination of "Most Probable Number". J Microbiol Methods 1, 133-137.

40. Yu Z \& Morrison M (2004) Improved extraction of PCRquality community DNA from digesta and fecal samples. Biotechniques 36, Suppl. 5, 808-812.

41. Denman S \& McSweeney C (2006) Development of a real-time PCR assay for monitoring anaerobic fungal and cellulolytic bacterial populations within the rumen. FEMS Microbiol Ecol 58, 572-582.

42. Lowe S, Theodorou M, Trinci A, et al. (1985) Growth of anaerobic rumen fungi on defined and semi-defined media lacking rumen fluid. J Gen Microbiol 131, 2225-2229.

43. Jouany J (1982) Volatile fatty acid and alcohol determination in digestive contents, silage juices, bacterial cultures and anaerobic fermentor contents. Sci Aliments 2, 131-144.

44. Sauvant D, Chapoutot P \& Archimède H (1994) La digestion des amidons par les ruminants et ses conséquences (Starch digestion by ruminants and its consequences). INRA Prod Anim 7, 115-124.

45. Statistical Analysis Systems Institute (2003) Statistical Analysis Systems, 8th. ed. Cary, NC: SAS Institute, Inc.

46. Littell RC, Henry PR \& Ammerman CB (1998) Statistical analysis of repeated measures data using SAS procedure. J Anim Sci 76, 1216-1231.

47. Gordon H \& Pesti L (1971) The gnotobiotic animal as a stool in the study of host microbial relationships. Bacteriol Rev 35, Suppl. 4, 390-429.

48. Savage D (1977) Microbial ecology of the gastrointestinal tract. Ann Rev Microbiol 31, 107-133.

49. Jiménez E, Marin M, Martin R, et al. (2008) Is meconium from healthy newborn actually sterile? Res Microbiol 159 187-193

50. Kukkonen K, Savilahti E, Haahtela T, et al. (2007) Probiotics and prebiotic galacto-oligosaccharides in the prevention of allergic diseases: a randomized, double-blind, placebocontrolled trial. J Allergy Clin Immunol 119, Suppl. 1, 192-198.

51. Buddington R \& Sangild P (2011) Companion animals symposium: development of the mammalian gastrointestinal tract, the resident microbiota, and the role of diet in early life. J Anim Sci 89, 1506-1519.

52. Shimomura Y \& Sato H (2006) Fecal D- and L-lactate, succinate, and volatile fatty acids levels in young dairy calves. J Vet Med Sci 68, Suppl. 9, 973-977.

53. Louis P, Scott K, Duncan S, et al. (2006) Understanding the effects of diet on bacterial metabolism in the large intestine. J Appl Microbiol 102, 1197-1208.

54. Belenguer A, Duncan SH, Graham Calder A, et al. (2006) Two routes of metabolic cross-finding between Bifidobacterium adolescentis and butyrate-producing anaerobes from the human gut. Appl Environ Microb 72, 3593-3599.

55. Duncan SH, Holtrop G, Lobley GE, et al. (2004) Contribution of acetate to butyrate formation by human faecal bacteria. Br J Nutr 91, 915-923. 
56. Belanche A, Balcells J, de la Fuente G, et al. (2010) Description of development of rumen ecosystem by PCR assay in milk-fed, weaned and finished lambs in an intensive fattening system. J Anim Physiol Anim Nutr 94, 648-658.

57. Rey M, Enjalbert F \& Monteils V (2012) Establishment of ruminal enzyme activities and fermentation capacity in dairy calves from birth through weaning. J Dairy Sci 95, $1500-1512$.

58. Fonty G, Gouet P, Jouany J, et al. (1987) Establishment of the microflora and anaerobic fungi in the rumen of lambs. J Gen Microbiol 133, 1835-1843.

59. Uyeno Y, Sekiguchi Y \& Kamataga Y (2010) rRNA-based analysis to monitor succession of faecal bacterial communities in Holstein calves. Lett Appl Microbiol 51, 570-577.

60. Fonty G, Gouet P \& Nebout JM (1989) Development of cellulolytic microflora in the rumen of lambs transferred into sterile isolators a few days after birth. Can J Microbiol 35, 416-422.

61. Edwards C \& Parrett A (2002) Intestinal flora during the first months of life: new perspectives. Br J Nutr 88, S11-S18.
62. Doreau M (1991) Le lait de jument (Mare's milk). INRA Prod Anim 4, Suppl. 4, 297-302.

63. Julliand V, de Fombelle A, Drogoul C, et al. (2001) Feeding and microbial disorders in horses: part 3 - effect of three hay:grain ratios on microbial profile and activities. $J$ Equine Vet Sci 21, Suppl. 11, 543-546.

64. Marinier S \& Alexander A (1995) Coprophagy as an avenue for foals of the domestic horse to learn food preferences from their dams. I Theor Biol 173, 121-124.

65. Perez P, Doré J, Leclerc M, et al. (2007) Bacterial imprinting of the neonatal immune system: lessons from maternal cells? Pediatrics 119, e $724-\mathrm{e} 732$

66. Hunt K, Foster J, Forney L, et al. (2011) Characterisation of the diversity and temporal stability of bacterial communities in human milk. PLoS One 6, Suppl. 6, e21313.

67. NRC (2006) Nutrient Requirements of Horses, 6th revised ed. Washington, DC: National Academy Press.

68. Martin-Rosset W, Andrieu J, Vermorel M, et al. (2006) Routine methods for predicting the net energy and protein values of concentrate for horses in the UFC and MADC systems. Livest Sci 100, 53-69. 